\title{
Distribution, den characteristics and diet of the Indian Fox Vulpes bengalensis (Mammalia: Canidae) in Karnataka, India: preliminary observations
}

\author{
H.N. Kumara ${ }^{1}$ \& Mewa Singh ${ }^{2,3}$ \\ ${ }^{1}$ Sálim Ali Centre for Ornithology and Natural History, Anakatti Post, Coimbatore, Tamil Nadu 641108, India \\ ${ }^{2}$ Biopsychology Laboratory, University of Mysore, Manasagangotri, Mysore, Karnataka 570006, India \\ ${ }^{3}$ Evolutionary and Organismal Biology Unit, Jawaharlal Nehru Centre for Advanced Scientific Research, Bengaluru, Karnataka, India \\ Email: ${ }^{1}$ honnavallik@gmail.com, ${ }^{2}$ mewasingh@bsnl.in (corresponding author)
}

Though historic accounts recognized four species of foxes from the Indian subcontinent (Pocock 1936), more recent accounts indicate the occurrence of only two species including the Indian Fox Vulpes bengalensis and the Red Fox $V$. vulpes with three distinct subspecies of the Red Fox: the mountain form 'Tibetan Fox' (V.v. montana), northern desert form 'Kashmir Fox' (V.v. griffithii) and a western desert form 'Desert Fox' (V.v. pusilla) (Prater 1980). The Indian Fox is the most common fox and it is known to have a wide distribution extending from the foothills of the Himalaya to the southern tip of peninsular India;

Date of publication (online): 26 November 2012 Date of publication (print): 26 November 2012 ISSN 0974-7907 (online) | 0974-7893 (print)

Editor: A.J.T. Johnsingh

\section{Manuscript details:}

Ms \# 03046

Received 24 December 2011

Final received 31 October 2012

Finally accepted 02 November 2012

Citation: H.N. Kumara \& Mewa Singh (2012). Distribution, den characteristics and diet of the Indian Fox Vulpes bengalensis (Mammalia: Canidae) in Karnataka, India: preliminary observations. Journal of Threatened Taxa 4(14): 3349-3354.

Copyright: () H.N. Kumara \& Mewa Singh 2012. Creative Commons Attribution 3.0 Unported License. JoTT allows unrestricted use of this article in any medium for non-profit purposes, reproduction and distribution by providing adequate credit to the authors and the source of publication.

Acknowledgements: This study was supported by the Department of Science and Technology, Government of India (Grant No. SP/SO/C-16/99) to Dr. Mewa Singh and Karnataka Forest Department to Dr. H.N. Kumara. We thank the Chief Wildlife Warden and the officials of the Karnataka Forest Department for permission to carry out this study and for assistance in the field. Special thanks are due to Mr. A.K. Varma. We acknowledge the support of Raghunath Rao, Shanthala Kumar, Somashaker, H.P. Ashwin and N. Subhashchandra for helping us in the field. We thank Shanthala Kumar for preparing the map.

urn:Isid:zoobank.org:pub:94053D67-FB8D-4B8D-879C-F999A7EAA6EE

\section{OPEN ACCESS | FREE DOWNLOAD}

Abstract: The Indian Fox Vulpes bengalensis inhabits relatively dry areas with scrub thorn forests, deciduous forests, short grasslands and marginal croplands. Since it is a widely distributed species, especially in the dry tracts, very little attention has been paid to it by researchers and wildlife managers. We conducted an extensive survey in the south Indian state of Karnataka to determine the conservation status of the Indian Fox. We also carried out a more detailed observation in a small region called "Jayamangali Blackbuck Block" (JBB) and surrounding private lands to study the den site characteristics of the species. Except for a few districts in the Western Ghats and the west coastal region, the fox was present throughout Karnataka. Relatively higher encounter rates were observed in regions with extensive grasslands. We located 52 dens during the study in JBB which provide a minimum of $12 \mathrm{dens} / \mathrm{km}^{2}$ with $1.33 / \mathrm{km}^{2}$ active dens. Circumference of den sites were smaller in JBB than in the adjoining private lands indicating that foxes frequently shifted dens in this area. The number of openings and active openings increased as the circumference of the den site increased. Fecal analysis revealed remains of certain species of plants, vertebrates and invertebrates, with arthropods as the major food items of the fox.

Keywords: Den characteristics, diet, distribution, Indian Fox, Karnataka.

from Sindh province of Pakistan on the Western side to southern Bangladesh on the eastern side (Johnsingh 1978, 1986; Prater 1980).

The Indian Fox is known to inhabit relatively dry areas, including scrub thorn forests, deciduous forests, short grasslands and marginal areas of croplands. The known range of the species falls within the biogeographical zones of desert (Zone 3), semi-arid (Zone 4) and the Deccan Peninsula (Zone 6) of India (Rodgers et al. 2002). The Indian Fox has been accorded the status of Schedule II in the Wildlife (Protection) Act, 1972 in India and classified globally as 'Least Concern' by the IUCN Red List of Threatened Species (Johnsingh \& Jhala 2007).

Since the Indian Fox has a wide distribution and is considered as a relatively common carnivore in India, it has received little attention from both researchers and managers. Despite the few studies on its ecology 
and behavior (Johnsingh 1978), population estimation in Rollapadu Wildlife Sanctuary in Andhra Pradesh (Manakadan \& Rahmani 2002), resource utilization (Home 2005), distribution in southern India (Vanak 2005) and habitat selection (Bhaskaran 2006), the biology and conservation status of the Indian Fox is poorly known. Vanak (2005) in a survey of fox in southern India included only five districts of Karnataka. In this paper, we present preliminary observations on the distribution of Indian Fox, its den site characteristics and diet in the state of Karnataka.

\section{Study area}

We conducted the present study in the southern Indian state of Karnataka, which is located between $11^{0} 31^{\prime}-18^{\circ} 45^{\prime} \mathrm{N} \& 7^{\circ} 12^{\prime}-78^{\circ} 40^{\prime} \mathrm{E}$. Karnataka covers a total area of $191,791 \mathrm{~km}^{2}$. Rainfall in this state gradually declines from west to east resulting in different forest or habitat types. The state receives a mean annual rainfall of $1,975 \mathrm{~mm}$ ranging from $450 \mathrm{~mm}$ in the drier plains on the eastern side to $7,500 \mathrm{~mm}$ in the Western Ghats on the western side. Karnataka has been divided into four ecozones including coastal Karnataka with mangrove forests, hill region (the Western Ghats) with rainforests and moist deciduous forests, southern plateau and northern plateau with deciduous forests, scrub forests and open grasslands (Prasad et al. 1978; Karanth 1986). We studied the den site characteristics at 'Jayamangali Blackbuck Block' (JBB) near Maidanahalli in Madhugiri Taluk, Tumkur District. The area of this block was about $3 \mathrm{~km}^{2}$, which lies between $77^{0} 18^{\prime}-77^{\circ} 20^{\prime} \mathrm{E} \& 13^{\circ} 44^{\prime}-$ $13^{0} 16^{\prime} \mathrm{N}$. The area has mainly grasslands with few thorny shrubs, and some monoculture plantations of Acacia auriculiformis and Eucalyptus grandis. It is an area meant for the protection of Blackbucks Antelope cervicapra. The area receives $400-500 \mathrm{~mm}$ of rainfall per annum and harbours $400-550$ blackbucks.

\section{Methods}

The study was carried out from January 2002 to July 2006. During this period, we traveled across different 'taluks' of all the 'districts' of the state, either by jeep or by motorcycle. We carried out a vehicular road survey of $9,853 \mathrm{~km}$ for direct sightings of foxes. During this survey, we also informally interviewed over 1400 people including forest department officials, shepherds, local sheepherders, villagers and others interested in wildlife. We collected secondary data through interactions with people on the possible occurrence of the species in each taluk. If more than $50 \%$ of the people in a taluk gave a positive response regarding the occurrence of the fox, we considered the fox as 'present' in the taluk. We also collected information on the occurrence of den sites, and if the den site was close by, we visited it for confirmation and attempted to sight the fox. We based den classification as per Johnsingh (1978) into three types: simple short dens, complex cavernous dens, and dens under rocks and we followed the same classification. We conducted $644 \mathrm{~km}$ of night surveys for foxes that included driving and walking transects in open scrub forests, grasslands and marginal cropland areas in 12 districts. During a driving survey, a researcher spotlighted from atop a jeep moving at a speed of $5-10 \mathrm{~km} / \mathrm{hr}$, and during walks we used a handheld flashlight to spot foxes. We also made walks in many other districts of the western coast and the Western Ghats. Since there was neither secondary information nor direct sightings of the fox in these districts, details on these sampling efforts are not provided. We also attempted direct sightings by flushing foxes from some active dens.

We selected Jayamangali Blackbuck Block (JBB) to investigate specific details on the characteristics of den sites and fox abundance. We selected $3 \mathrm{~km}^{2}$ of JBB and about $10 \mathrm{~km}^{2}$ of private area around this block for abundance estimates. The entire region was searched thoroughly for the presence of all abandoned and active dens of the foxes by a five member team during March-April 2004. We recorded details on each den site that included status, distance from cropland, area, number of openings, number of active openings, and length and width of each den opening. A total of 81 droppings were collected from the JBB near the active dens, which were used to identify the food items.

\section{Results}

There was no evidence for the occurrence of the Indian fox from the coastal region and forests of the Western Ghats. The foxes were found in all the dry plains of Karnataka in the east, extending up to the eastern fringes of evergreen forests of the Western Ghats in the west and northern fringes of deciduous forests in the south (Fig. 1, Table 1). The population distribution was continuous with the fox populations in the states of Maharashtra in the north, Andhra 


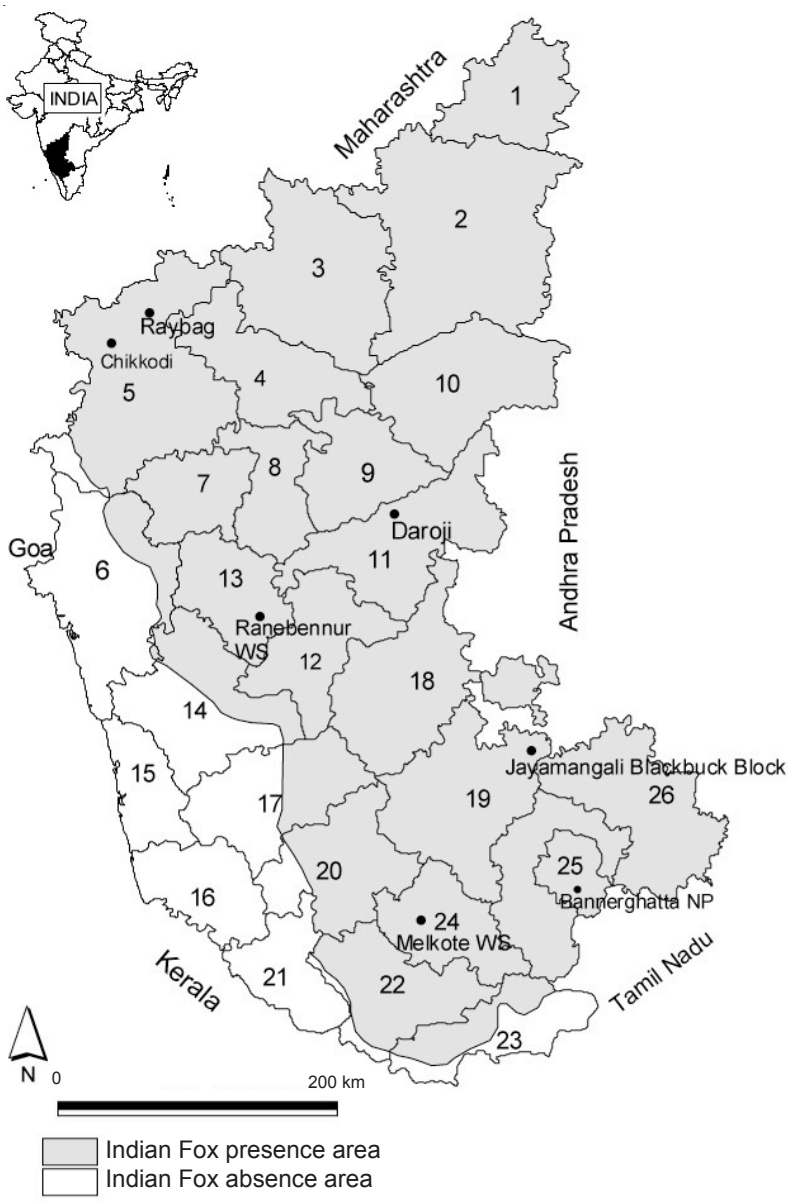

Figure 1. Distribution of Vulpus bengalensis in Karnataka, India. Numbers inside the figure indicate revenue districts (see Table 1)

Pradesh in the east and Tamil Nadu in the south. The present distributional range covers six protected areas in Karnataka that include Daroji Bear Sanctuary and Ranebennur Wildlife Sanctuary in the north, and Melkote Temple Wildlife Sanctuary, Arabithittu Wildlife Sanctuary, Ranganathittu Bird Sanctuary and Bannerghatta National Park in the south. Local people revealed the occurrence of Indian Fox at the northern fringes of Bandipur Tiger Reserve and Nagarahole Tiger Reserve. Though the foxes occur in the abovementioned wildlife protected areas, they are mostly found near the fringes and close to the croplands.

We sighted a total of 36 foxes at night time during this study (Table 2). Most foxes were observed in Chikodi and Raibag of Belgaum District and Madhugiri in Tumkur District. All the sightings in both regions were in the grasslands, and $78 \%(\mathrm{~N}=28)$ of the sightings were associated with the grassland.

We identified 56 dens, 52 of which were in and
Table 1. Occurrence of the Indian Fox in different districts of Karnataka

\begin{tabular}{|c|c|c|c|}
\hline No.* & District & $\begin{array}{l}\text { Occurrence }^{1} \\
\text { (evidence) }^{2}\end{array}$ & Remarks \\
\hline 1 & Bidar & $P(2,3)$ & Occur in all taluks \\
\hline 2 & Gulbarga & $P(1)$ & Occur in all taluks \\
\hline 3 & Bijapur & $P(1)$ & Occur in all taluks \\
\hline 4 & Bagalkot & $P(2,3)$ & Occur in all taluks \\
\hline 5 & Belgaum & $P(1)$ & $\begin{array}{l}\text { Occur in all taluks, except } \\
\text { some parts of Khanapur } \\
\text { taluk }\end{array}$ \\
\hline 6 & $\begin{array}{l}\text { Uttara } \\
\text { Kannada }\end{array}$ & $P(1)$ & $\begin{array}{l}\text { Occur only in Mundagod } \\
\text { taluk }\end{array}$ \\
\hline 7 & Dharwad & $P(2,3)$ & Occur in all taluks \\
\hline 8 & Gadag & $P(2,3)$ & Occur in all taluks \\
\hline 9 & Koppal & $P(2,3)$ & Occur in all taluks \\
\hline 10 & Raichur & $P(2,3)$ & Occur in all taluks \\
\hline 11 & Bellary & $P(1)$ & Occur in all taluks \\
\hline 12 & Davangere & $P(2,3)$ & Occur in all taluks \\
\hline 13 & Haveri & $P(1)$ & Occur in all taluks \\
\hline 14 & Shimoga & $P(2,3)$ & $\begin{array}{l}\text { In Bhadravati, Shimoga, } \\
\text { Shikaripur taluks }\end{array}$ \\
\hline 15 & Udupi & $\mathrm{AB}$ ? & - \\
\hline 16 & $\begin{array}{l}\text { Dakshina } \\
\text { Kannada }\end{array}$ & $A B ?$ & - \\
\hline 17 & Chikmagalur & $P(1)$ & $\begin{array}{l}\text { In Kadur, Chikmagalur and } \\
\text { Tarikere taluks }\end{array}$ \\
\hline 18 & Chitradurga & $\mathrm{P}(2,3)$ & Occur in all taluks \\
\hline 19 & Tumkur & $P(1)$ & Occur in all taluks \\
\hline 20 & Hassan & $P(2,3)$ & $\begin{array}{l}\text { In Belur, Hassan, Arasikere, } \\
\text { HoleNarasipur and } \\
\text { Chandrayapattana taluks }\end{array}$ \\
\hline 21 & Kodagu & $\mathrm{AB}$ ? & - \\
\hline 22 & Mysore & $P(1)$ & Occur in all taluks \\
\hline 23 & Chamarajnagar & $\mathrm{P}(2,3)$ & Occur in all taluks \\
\hline 24 & Mandya & $P(1)$ & Occur in all taluks \\
\hline 25 & Bangalore & $P(1)$ & Occur in all taluks \\
\hline 26 & Kolar & $P(1)$ & Occur in all taluks \\
\hline
\end{tabular}

${ }^{*}$ No.: Numbers depict the districts in the Figure 1.

${ }^{1} \mathrm{P}$ - Present; AB - Absent

21 - Sighted; 2 - Den site and fecal deposit; 3 - Local information

around the JBB in Madhugiri where we had intensively explored the dens. Among the 52 dens, 36 were located in JBB and the other 16 were located in nearby private croplands and marginal areas. During our study, all three types of dens were found in the study area. One den was in an abandoned quarry. Most of the dens in the JBB were simple dens and only a few were complex dens. The minimum number of dens was 12/ $\mathrm{km}^{2}$ and $1.6 / \mathrm{km}^{2}$ in JBB and private areas, respectively. 
Table 2. Sight records of the Indian fox in different drier regions of the Karnataka

\begin{tabular}{|l|c|c|l|}
\hline Area & $\begin{array}{l}\text { Km covered } \\
\text { during night }\end{array}$ & Sightings & $\begin{array}{l}\text { Taluks in which } \\
\text { sighted }\end{array}$ \\
\hline Gulbarga & 45 & 2 & Yadgir \\
\hline Bijapur & 26 & 1 & Basavana Bagevadi \\
\hline Belgaum & 82 & 10 & Chiokkodi and Raibag \\
\hline Uttara Kannada & 30 & 1 & Mundgod \\
\hline Bellary & 45 & 1 & Hospet \\
\hline Haveri & 22 & 1 & Ranebennur \\
\hline Chikmagalur & 35 & 1 & Kadur \\
\hline Tumkur & 105 & 11 & Madhugiri and Sira \\
\hline Mysore & 48 & 4 & Mysore and HD Kote \\
\hline Mandya & 12 & 1 & Pandavapura \\
\hline Bangalore & 102 & 1 & Hoskote \\
\hline Kolar & 92 & 2 & Bagepalli \\
\hline Total & $\mathbf{6 4 4}$ & $\mathbf{3 6}$ & \\
\hline
\end{tabular}

However, the minimum density of active dens in JBB was $1.33 / \mathrm{km}^{2}$, whereas in the private areas it was $1.3 /$ $\mathrm{km}^{2}$. Mean $\pm \mathrm{SE}$ den site area was $10.17 \pm 6.67 \mathrm{SE}$ $\mathrm{m}^{2}$ in JBB, which was significantly smaller $(\mathrm{t}=4.35$, $\mathrm{df}=51, \mathrm{p}<0.001)$ than the mean circumference in the private area $\left(24.75 \pm 17.64 \mathrm{SE} \mathrm{m}^{2}\right)$. The mean number of openings per den site in JBB was 4.11 $\pm 3.46 \mathrm{SE}$ and in the private area was $1.69 \pm 11.77 \mathrm{SE}$. The mean \pm SE active openings of active den sites in JBB were $1.00 \pm 0.00 \mathrm{SE}$ and in the private area were $6.69 \pm 4.87$ SE. The number of openings (Pearson correlation; $r=$ 0.766, $\mathrm{N}=52, \mathrm{p}<0.01$ ) and active openings (Pearson correlation; $r=0.729, \mathrm{~N}=52, \mathrm{p}<0.01)$ increased as the circumference of the den site increased.

The average and the maximum distance between den sites and cropland were about $400 \mathrm{~m}$ and $1100 \mathrm{~m}$, respectively. All the den sites and fox sightings were in open areas with grassland or scrub forests. Even if the dens were in scrub forests, they were all located in large open areas at least $50 \mathrm{~m}$ from the nearest thick bushes, except two dens that were located beneath thick bushes. Fecal analysis identified remains of plants, invertebrates and vertebrates. Arthropods were the major invertebrates found in the scats (95\%) that included different insects, centipedes, land crabs and termites. However, termites were found only in three scats. Undigested plant remains, seeds and fruits occurred in $81 \%$, rodents occurred in $80 \%$ and reptiles occurred in $12 \%$ of the scats. Among reptiles, the worm snake Typhlops spp. was recorded in six scats. Other mammals, birds, egg shells and frogs collectively occurred in $<10 \%$ of the scats.

Interviews revealed that killing of fox by people occurs throughout much of Karnataka. In most places, foxes are hunted for meat (especially by a community called Nari Kurava). Conversely, fox has been considered as a symbol of good omen. Hence, people in rural areas have a tendency to keep a fox skin in their shops. They also believe that a holy thread, the skin of a fox tied in a thread prepared by village priests and astrologers, would solve their problems, and they tie this thread on their wrists.

\section{Discussion}

Historically, the Indian Fox has not been recorded from the Western Ghats (Johnsingh \& Jhala 2004) as the terrain and vegetation do not favor their occurrence there. Our study provides the first distribution estimate of the Indian Fox in the entire southern Indian state of Karnataka, which confirmed the absence of the species in the forests of the Western Ghats, coastal region and the thick deciduous forests of the Eastern Ghats. The present study also confirms the presence of fox in the predicted distribution range (both generic and refined distribution range) in the state (Vanak et al. 2008). Since the Indian Fox appears to have a high degree of tolerance to human disturbance, Bhaskaran (2006) suggested that the species is a 'habitat generalist'. However, despite its wide range, the Indian Fox generally occurs in high densities in grassland habitats. Vanak (2005) and Manakadan \& Rahmani (2002) also reported the highest density of Indian Fox in grassland habitats in southern India. Our study also revealed two major populations in Chikodi and Raibag of Belgaum District and Madhugiri in Tumkur District, which were found in grasslands with sparse scrub forest. Further, though the Indian fox has a high degree of adaptation to its habitat (Bhaskaran 2006), they have a low level of tolerance to disturbance. For example, Karanth \& Singh (1986) reported that the Indian Fox was the most common carnivore and sighted very frequently in Ranebennur Wildlife Sanctuary. Later, Vanak (2005) during his survey in the same region did not observe a single fox in and around the sanctuary, and ascribed this to conversion of grassland into Eucalyptus plantations. Since large extents of open grasslands and scrub forests are available in the Indian subcontinent, 
the species may have a wider distribution. Since foxes live in human dominated landscapes, they are also prone to infection by many diseases. Manakadan \& Rahmani (2002) reported a sharp decline of foxes in Rollapadu Wildlife Sanctuary in Andhra Pradesh and Johnsingh \& Jhala (2007) reported a similar decline in parts of Gujarat, which were attributed to pathogens (Gompper \& Vanak 2006).

The diet of Indian Fox generally includes a large variety of plants, invertebrates and vertebrates (Johnsingh 1978; Home 2005; Gompper \& Vanak 2006; Home \& Jhala 2009). Though the same food items were identified in the present study also, the fecal samples collected in a short span of 40 continuous days from a small region in a single season may indicate the proportion of the diet content to be biased to a few food items. Our findings, however, are more similar to those from Rollapadu Wildlife Sanctuary in Andhra Pradesh and Ranebennur Wildlife Sanctuary in Karnataka where $85 \%$ of scats contained remains of invertebrates with large proportions of arthropods (Gompper \& Vanak 2006). Plant remains and rodents were found to be the next major food items in Karnataka, which is of a comparatively higher proportion than in the other regions in India (Manakadan \& Rahmani 2000; Home 2005; Gompper \& Vanak 2006). Since rodents form the major part of its diet, Advani (1987) suggested that the Indian Fox plays a major role in controlling rodent populations. Centipedes, land crabs and bird eggs were also reported as food items in different regions (Pocock 1941; Prakash 1959; Johnsingh 1978; Prater 1980; Manakadan \& Rahmani 2002; Johnsingh \& Jhala 2004).

Johnsingh (1978) reported eight dens per square kilometer, whereas in our study, the number varied from 1.6 to 12 dens per square kilometer. The number of entrances varied from one to 36 in our study area, which is higher than the number of entrances reported in Tamil Nadu (Johnsingh 1978). However, the number of entrances differed between the JBB and its surrounding area. This may be attributed to the difference in the response to characteristics of the habitat. Though the density of active dens did not differ between the JBB and private areas, the number of passive dens in JBB was very high. Conversely, den site area was very high in private areas, which suggests that foxes frequently shift dens in JBB than in the private areas. However, Johnsingh (1978) suggested that the Indian Fox repeatedly uses 'favorite' den sites such as those among the cluster of large rocks as they are largely safe from vandalism by humans that has also been reported for the Red Fox in North America (Murie 1944; Ables 1975). In private areas with croplands, villages and regular movement of people, the denning habitat is probably lesser than in JBB. This may result in larger den sites with more entrances in private areas. Several entrances are not uncommon among foxes (e.g. many entrances were reported for the Red Fox in North America (Murie 1944; Ables 1975) and Arctic Fox (Alopex lagopus) (Chesemore 1969).

It often happens that species considered as common with a wide range of distribution do not receive the same attention in management as compared to those listed as high priority species. We emphasize that these species also require adequate management. Vanak \& Gompper $(2010 \mathrm{a}, \mathrm{b})$ reported that though the free ranging domestic dogs do not have a high food niche overlap with the fox, they may prevent access to foxes to the agricultural areas and grassland which are preferred habitats of the fox; and dogs do kill foxes. Elimination of free-ranging dogs is a must if we want to save many of our wildlife. We suggest that killing of foxes by people should be totally stopped and that the number of free-ranging dogs in fox habitats should be controlled. Certain communities have the false belief that body parts of the fox kept at home bring wealth and these communities need to be educated. Already local extirpation of the fox has occurred in several places and this needs to be arrested before the fox also gains the dubious status of an endangered species.

\section{REFERENCES}

Ables, E.D. (1975). Ecology of the Red Fox in North America, pp. 216-236. In: Fox, M.W. (ed.). The Wild Canids. Van Nostrand Reinhold Company, New York.

Advani, R. (1987). Rodent damage to various annual and perennial crops of India and its management, pp. 108-112. In: Eighth Great Plains Wildlife Damage Control Workshop. South Dakota, Rapid City.

Bhaskaran, A. (2006). Modelling Habitat Selection of the Indian Fox (Vulpes bengalensis) in and around the Great Bustard Wildlife Sanctuary, Nannaj, Maharashtra. M.S. Thesis, The Manipal Academy of Higher Education (Deemed University), Karnataka, India.

Chesemore, D.L. (1969). Den ecology of the Arctic Fox in 
Northern Alaska. Canadian Journal of Zoology 87: 121129.

Gompper, M.E. \& A.T. Vanak (2006). Vulpes bengalensis. Mammalian Species 795: 1-5.

Home, C. (2005). Resource Utilization by the Indian Fox Vulpes bengalensis in Kutch, Gujarat. M.S. Thesis. Saurashtra University, Rajkot, India.

Home, C. \& Y.V. Jhala (2009). Food habitas of the Indian Fox (Vulpes bengalensis) in Kutch, Gujarat, India. Mammalian Biology 74: 430-411

Johnsingh, A.J.T. (1978). Some aspects of the ecology and behaviour of the Indian Fox Vulpes bengalensis. Journal of the Bombay Natural History Society 75: 397-405.

Johnsingh, A.J.T. (1986). Diversity and conservation of carnivorous mammals in India. Proceedings of the Indian Academy of Sciences (Suuplement): 73-89.

Johnsingh, A.J.T. \& Y.V. Jhala (2004). Indian Fox (Vulpes bengalensis), pp. 219-22. In: Sillero-Zubiri, M.H.C. \& D.W. Macdonald (eds.). Canids: Foxes, Wolves, Jackals and Dogs: Status Survey and Conservation. IUCN/SSC, Gland, Switzerland.

Johnsingh, A.J.T. \& Y.V. Jhala (2007). Vulpes bengalensis. In: IUCN 2010. 2010 IUCN Red List of Threatened Species $<$ www.iucnredlist.org $>$. Downloaded on 23 December 2011.

Karanth, K.U. (1986). Status of wildlife and habitats in Karnataka. Journal of the Bombay Natural History Society 83: 166-179.

Karanth, K.U. \& M. Singh (1986). Dry zone afforestation and its impact on Blackbuck populations. Journal of the Bombay Natural History Society (Centenary Proceedings): 565-570.

Manakadan, R. \& A.R. Rahmani (2002). Population and ecology of the Indian Fox Vulpes bengalensis at Rollapadu Wildlife Sanctuary, Andhra Pradesh, India. Journal of the
Bombay Natural History Society 97: 3-14.

Murie, A. (1944). The Wolves of Mount Mckinley. U.S National Parks. Fauna Series 5, Washington D.C., 232pp.

Pocock, R.I. (1936). The foxes of British India. Journal of the Bombay Natural History Society 39: 36-57.

Pocock, R.I. (1941). Fauna of British India, including Ceylon and Burma. Mammalia. Volume II. Carnivora (continued from Volume I), Suborders Aeluroidea and Arctoidea. Taylor and Francies, London, 503pp.

Prakash, I. (1959). Food of some Indian mammals. Journal of Biological Sciences 2: 100-109.

Prasad, S.N., V.P. Nair, H.C. Sharathchandra \& M. Gadgil (1978). On factors Governing the distribution of wild mammals in Karnataka. Journal of the Bombay Natural History Society 75: 718-743.

Prater, S.H. (1980). The Book of Indian Animals. Bombay Natural History Society, Mumbai, 326pp.

Rodgers, W.A., H.S. Panwar \& V.B. Mathur (2002). Wildlife Protected Area Network in India: a review (Executive Summary), Wildlife Institute of India, Dehradun, 14-17pp.

Vanak, A.T. (2005). Distribution and status of the Indian Fox Vulpes bengalensis in southern India. Canid News 8: 1.

Vanak, A.T. \& M.E. Gompper (2010a). Dietary niche separation between sympatric free-ranging domestic dogs and Indian foxes in central India. Journal of Mammalogy 90: 1058-1065.

Vanak, A.T. \& M.E. Gompper (2010b). Inteference competition at the landscape level: the effect of free-ranging dogs on a mesocarnivore. Journal of Applied Ecology 47: $1225-1232$.

Vanak, A.T., M. Irfan-Ullah \& A.T. Peterson (2008). Gap analysis of Indian Fox conservation using ecological niche modeling. Journal of the Bombay Natural History Society 105: 49-54. 